\title{
Populism: What Is and Why We Need A Multidimensional Approach to Understand it
}

\author{
Giorgio C.S., Giraudi, (Associate Professor) \\ Università della Calabria, Italy
}

Doi: 10.19044/esj.2018.v14n8p16 URL:http://dx.doi.org/10.19044/esj.2018.v14n8p16

\begin{abstract}
Populism is the 'new big thing' in western politics. On both sides of the Atlantic Ocean, populist leaders, movements and parties are obtaining a growing political consent. Staring from this empirical evidence, the article reconstructs the three main strands that constitute the scientific reflexion on populism showing the limits that every single strand have and proposing a new definition of populism based on a multidimensional and syncretic approach that can account for the complexity of the normative common roots that link populism to democratic theory.
\end{abstract}

Keywords: Populism, Democracy, Political science

\section{Introduction}

In introducing a famous volume edited by the two scholars and published in 1969, in which some leading scholar tried to systematize the debate on populism which was helded in 1967 at the London School of Economics (Ionescu \& Gellner, 1969), Ghita Ionescu and Ernest Gellner, paraphrasing a more famous political 'Manifesto', claimed that 'a spectrum is wandering around the world: populism'. Fifty years later, that categorical affirmation seems to be more real than ever, almost nothing has changed in spite of such a length of time that has seen a radical transformation of the entire planet. Though, at the end of the seventies, populism seemed to be a 'residual' political phenomenon, mainly limited to some Latin American states and in the run-out. But today, once again, populism seems to confirm its 'karstic' and potentially ubiquitous nature. This, after more or less long periods during which it almost completely loses its tracks, in the result of an absent or marginal element of the political process, reappeared in unexpected places and forms to raise his challenge to democracy once again, as if democracy itself can never be permanently free of it, that it is for some reason never definitively clarified forced to infinite coexistence more or less turbulent with this host so cramped and elusive as, often undesirable. 
The sensation, largely supported by the scientific literature, is that populism and democracy share inevitably elements of foundation, a common 'nature' that renders democratic practice impossible without being present in a latent or manifest form even with a certain degree of populism. To question the populist challenge to democracy, means first of all, to try to define in a sufficiently clear way the two terms of the report that you want to investigate. Only a careful and articulated conceptualization of populism and democracy can provide the explanatory elements needed to answer the questions posed by the very idea of a populist challenge to democracy.

\section{I.}

What is the relationship between populism and democracy, then? With reference to the now extensive literature on populism, it can be stated that currently, there is no consensus on the type of relationship that populism establishes with democracy. A very narrow review of this literature suggests, in fact, highly differentiated and often contrasting visions of our object of investigation. For example, the philosopher Torbjörn Tännsjö, arguing around the various forms of ideals and practices of democracy, defined populism as the "purest form of democracy" (Tännsjö, 1992) while, on the contrary, Nadia Urbinati repeatedly warned readers of the subversive and undemocratic potential that would reside within the conceptual nucleus of populism (Urbinati, 1998; Urbinati, 2014). Likewise, Marco Tarchi, having noted that "All recent studies have led to the finding that the direct appeal to the people as a source of political sovereignty, placed outside and above any representation, is becoming more and more diffused" (Tarchi, 2015: 375) states that "(...) within populist optics democracy has a plebiscitary connotation and ends up being seen as plebiscite acclamation and not as a system of rules" (Ivi, pg.78).

In the midst of these cases that come to opposite conclusions, a plethora of authors has expressed intermediate positions proposing an idea of radical ambiguity between the relationship between populism and democracy. For example, in one of the most important works produced on the subject, Margaret Canovan clearly outlines the potential of democratic mobilization inherent in populist politics and suggests that populism is a 'shadow' of democracy ready to take form and consistency insofar as modern democracies are incapable of balancing the liberal-constitutional component with the participatory one attributable to the will of the people. Within this theoretical proposition, populism, in addition to being co-founded with the same democracy, would be "a redemptive political style that shakes within the structure of modern democracy against the alienating effects produced by the cold pragmatism of political representation" (Canovan, 1999) and, therefore, populism would essentially not be a deadly challenge to democracy, but rather 
as a corrective and an integration/ extension of democracy itself. And that the relationship between populism and democracy is pervaded by ambiguities and contradictions are also confirmed by other relevant authors such as Benjamin Arditi, Michael Kazin and Ernesto Laclau, who emphasize, with different accents and nuances, that populism, while presenting elements of ambiguity that make it potentially dangerous for democratic regimes making it not so much a 'shadow' as a 'spectrum' of democracy (Arditi, 2004), it must be and above all conceived as a policy strategy that is based and allows the inclusion of new social groups within the democratic process (Arditi, 2003; Kazin 1995; Laclau 2005) and prevent the oligarchic closure of political systems (Arditi, 2003). Thus, populism would be the main juncture map that would reveal what social conditions and demands are not sufficiently satisfied by contemporary democratic systems (Bobbio 1984, Taggart 2004, Arditi 2004; Arditi 2007, Laclau 2005). Populism would therefore be the most obvious symptom of a "political malaise" that would pervade contemporary democracies.

A 'malaise' is so widespread that even government parties, normally not cataloged within political actors of populist nature, take on political elements of populist rhetoric, thus generating a real populist contagion and a situation that Cas Mudde can define in terms of "populist Zeitgeist" (Mudde, 2014). Given the literature reached on populism and democracy may continue for a long time, however, I believe that the examples presented are sufficient to show that there is not enough agreement on the issue of relations between populism and democracy, and therefore every work that wants to deal with this theme must necessarily address the problem of why this consensus is missing and if and how to overcome this situation. At first sight, the field of study in question seems to be characterized by an excess of complexity. Concepts as broad as those of populism and democracy can be difficult to 'handle' altogether, and this 'thickness' of key concepts could produce excessive complexity of analysis when one wants to move towards the field of relationships that lie between them. However, in my opinion, the difficulty in focusing the relationships that necessarily lie between populism and democracy must be mainly attributed to a defect of partial conceptualization of the two terms and, consequently, to an equally partial or confused reading of their reciprocal relations. In most of the works that make up the bibliographic reference corpus, the effort to make these complex key concepts theoretically 'manageable' translates into an excess of schematism that produces too limited and peculiar optics to render justice to the complexity of the object of study. This results in a fragmented literature in which every author tends to propose his own idea of populism by highlighting some essential but not exhaustive aspects of the phenomenon and, consequently, partial and therefore almost inevitably contradictory conclusions. Partial definitions of the populist phenomenon are often associated with too 
schematic conception of democracy and the overall result is a subunderstanding of both phenomena and, above all, of the relationships that bind them so firmly in time. It is therefore necessary to re-establish the complexity of the phenomena studied in order to be able to better investigate their interrelations.

\section{Three ideas of populism}

In a famous essay of 1969, Isaiah Berlin called the Cinderella complex' of populism, that is, "there is a shoe in the form of populism, but no foot that can fit it perfectly" (Berlin, 1969; in Tarchi, 2014: 28). By proposing this paradox, it is evident that Berlin considers it possible and useful to find a stable and specific conceptual nucleus that would allow it to identify 'a heart', 'an essence' (Zanatta, 2002). The idea of defining the "cognitive and regulatory hard core" (Mény \& Surel, 2000: 279) of the concept of populism have adhered to various authors in time and in a growing way and it is therefore legitimate to identify in this part of the literature a first set of studies on populism that investigated it by researching its 'ideological' essence. The different authors who can be traced back to this approach share the idea, made explicit by Paul Taggart, that the different empirical cases of populism they can be traced back to a 'thin ideology' (Freeden, 1996; Taggart 2004) .Populism, therefore, would have "many attributes of ideology but not all" (Taggart, 2000; cited in Zanatta , 2002:15) In particular, populism would be "(...) an ideology that considers society permanently divided into two homogeneous and antagonistic groups, 'the pure people' against the 'corrupt elite', and who argues that politics should be the expression of the general will of the people " (Mudde 2014: 544).

At the thread that has focused its efforts in the direction of identifying the idealpictual and ideological elements that can share all the different experiences that have been cataloged within populism, historically has opposed a set of studies that defined the populist phenomenon in terms of 'political style' and 'political discourse'. This course of study (see for example: Canovan, 1999; Kazin, 1995; Taguieff, 1995; Laclau, 2005; Panizza, 2005; Chiapponi 2009; Jagers \& Walgrave, 2007; Hawking, Riding, \& Mudde, 2012). consisting of the work of authors who do not seek a definitive and idealtype definition of populism. The common starting point for these scholars is instead a performance of the language and, consequently, an emphasis on political discourses produced by political leaders. For example, according to the interpretation given by Francisco Panizza, scholars such as Peter Worsley, Edward Shills, Ernesto Laclau and Margaret Canovan share the idea that populism is "an appeal to the people against existing power structures" (Panizza et al. ., 2005: 10). Intended as a discursive style or a peculiar way of doing politics, populism is thus "an accessible way of identification for every 
political actor within a discourse field in which the notion of people's sovereignty and its inevitable corollary, the conflict between the powerful and those who do not have power, are central to his political imagination "(Panizza et al., 2005: 9). Within the discursive conception of politics, to say it with Laclau's words, "a movement is not populist because the politics or ideology it contains contains populist elements, but because it shows a particular logic of articulation of the contents, whatever they are" (Laclau, 2005:38). Within this scientific paradigm, the (political) discourse is by its nature constitutive (performative) and does not express a pre-existing and stable nature of the actor he speaks. It is useless for Laclau, and for authors who use the discursive approach to ask who is or is not a populist, the only sensible question is "to what extent is a populist movement?" (Laclau, 2005: 50). The discourse approach is thus more appropriate than the ideal-type approach to try to address the already mentioned Mudde affirmation with respect to the populist Zeitgeist which would be the figure identifying contemporary politics. Without postulating that all political actors have changed their ideology by assuming a populist, one can instead profoundly investigate to what extent and even political actors who are normally not considered 'populists' use rhetoric, style and discursive elements that produce "communicative frames cognitive "(Jagers \& Walgrave, 2007; Hawking, Riding \& Mudde, 2012), referring to populist speech.

There is, finally, a third possibility. I am referring to that line of studies that defines populism as a 'widespread mentality'. An example of this approach can be considered as the work of Marco Tarchi who studies populism from the concept of characteristic mentality as originally proposed by Juan Linz (Linz, 1975): "mentality is an intellectual attitude, 'ideology is an intellectual content; the first is psychic predisposition, the second is reflection, self-interpretation. " (Tarchi, 2015) And while "Mindset is ahead, the ideology follows. Still, mentality is devoid of form, fluctuating, while ideology is firmly formed. (...) Another important point is that, with regard to ideologies, mentalities show some vagueness; in fact, "we refer to generic values" and "we use the discrete and pragmatic incorporation of elements derived from the dominant ideological centers at the moment" (Ivi, pg. 51). As for the analysis of populism as a communicative style, however, according to the opinion of the writer, the perfectional power attributed to the populist leader has been reduced. It is capable of generating processes of symbolic integration by giving rise to a 'collective' (that is to its' people ') that previously did not exist in the form of political discourse and therefore of political conflict, yet its ability to' imagine and giving shape to the people 'is neither absolute nor less free from the social, psychological and cultural reality within which the leader is to operate. Within this perspective, Roberto Cartocci has identified, for example, the characteristic traits of a populist Italian culture that would be 
based on the various political forms of populism that have crossed our country over time (Cartocci, 1996; Tarchi, 2015). From these cultural and psychological elements, populism would then be presented as "a feeling, a moral attitude, or, rather, a reflection of a psychological, emotional and cognitive structure that pre-existent and produces" (Tarchi , 2015: 48).

\section{Populism as a multidimensional concept}

The three research strands that have been up to mentioned here have been presented and lived by many of the authors cited as mutually exclusive. From a strictly theoretical point of view, the tendency to proclaim its own research approach is the only valid for understanding the nature and dynamics of populism. On this point, the opinion who writes is that the degree of mutual exclusivity of the various approaches has been overwhelmingly exaggerated, and that this position depends in part on the need to distinguish and strengthen its scientific proposal, but also and above all by not having treated the populism as a multidimensional concept.

Unlike many other concepts, in fact, populism shares its core with some elements of democratic politics, and the latter reflects a fundamental property; that of power and duty to be conceived and studied simultaneously both as a 'normative ideal' and as 'empirical realization' (Sartori, 1993; Sartori, 2007). Populism is also composed of this dual soul, that normative, regarding the dimension of what must be and of the state of politics, and that of its epiphenomenic manifestations, of political practices, linguistic style and various form of leadership. And this dual nature not only must not be misunderstood or denied, but it must be used as a heuristic element to articulate and properly understand the challenges that on more than one level and in various forms populism advances towards democracy. The two concepts must therefore be compared on the two levels by distinguishing the normative dimension from the empirical one, well knowing that a level, though distinct and analyzable separately, then necessarily refers to the other. Using this method I hope to be able to demonstrate that much of the confusion that was detected at the very beginning of this essay is mainly due to the lack of this distinction for which we have finished comparing and evaluating either just one of the two dimensions or, erroneously, the normative side with the empirical dimension of the two concepts.

As has already been mentioned, the search for the idealtypic core of populism has generated various proposals. Among these proposals, what now seems to enjoy greater consensus is what defines populism as 'subtle ideology'. The limitation of this conceptualization, however, is that, to be acceptable, it has to resort to a very general and abstract definition of particular ideology. A definition that, therefore, because of the features mentioned above, is likely to be very 'general-generic' and to explain everything and nothing, to become a 
linguistic passepartout that very little offers us in terms of the specificity and intent of the concept and hence in terms of explanatory power. The incongruity of a concept like that of 'subtle ideology' can be usefully understood as soon as we use a definition that reflects more what the main ideologies of the last century were.

In this case we will find, for example, definitions like the following: "a generic term that can be applied to any political doctrine, to social movements characterized by theoretical elaboration, ideological-cultural orientation, and economic and social policy. Alongside this generic meaning, however, the term has retained a more specific and narrow meaning, which is used to indicate precise doctrines and political movements (communism, Nazism, Fascism), shared by some characteristics: the presence of a theoretical background more or less elaborated, which claims to provide an exhaustive (and definitive) explanation of historical and social processes; the attempt to totally transform society and man, according to a precise model; the intense emotional participation of militants, often similar to 'religious faith'; the leadership role of a party with a hectic and capillary organization " (Enciclopedia Treccani on-line; Voce: Populismo translated by the Author)

It is evident in this case that populism lacks virtually all of the features typical of ideology except for the normative dimension, and it is not enough to put the 'subtle' adjective to resolve the issue without submitting the concept of ideology to an undue 'stretch' (Sartori, 2011) that erodes much of the explanatory power as well as disconnects it from any historical analysis of the concept. Of ideology, populism does not have the broad theoretical elaboration necessary to codify thought systems (ideologies) which, starting with some key assumptions about human nature and social phenomena, define the path of history and link it to a political project radical that ultimately fulfills the emancipation of man or, in any case, the full deployment of his presumed 'nature'. Populism is a symbolic system with rather limited regulatory requirements (the task it is self-asserting is to 'put the true people on the throne of democracy') without a political project, without specific content, without specific and constant references to subsystems which is not that of politics. This is precisely one of the major singularities of the populist phenomenon; it is capable of generating strong feelings of identification and mobilization while remaining with a nucleus of meaning absolutely empty (Laclau, 2005 in Panizza et al., 2005) in terms of specific policy proposals and of subsystem regulation.

From a normative point of view, populism focuses entirely on an organic idea of the people (defined by default the only legitimate subject existing on the political scene) that is capable of expressing its own will which must become translated in the political and institutional decision-making without any changes or further interpretations. Populism is therefore an 
expression of a widespread mentality rather than representing some sort of teleological and emancipatory ideology, yet it does not diminish the widespread mentality from which it derives legitimacy and political consensus. Although it needs a social and psychological basis that has some specific features, populism retains its 'political autonomy' given by the leader's ability to express a performance function to evoke from time to time the 'people'. Populism is therefore, at the level of the regulatory system, an axiomatic and doctrinal interpretation of democracy (a concept that is similar to that of the 'disfigurement of democracy' proposed by Nadia Urbinati (Urbinati, 2014)), which focuses all around the idea of popular will as the only and united source of democratic legitimacy. Of ideological politics, populism retains the will and ability to create strong, non-negotiable identities. It is, therefore, ad absurdum, an ideological policy, that is to say a strong identification, which spreads just in the era of the conclamed dissolution of the political ideologies that characterized the period of mass democracy. And that populism has elements in common with political ideologies, although it does not present the essential characteristic of emancipatory teleological design, it is demonstrated by the fact that the same populism develops in many cases hybridizing precisely with pre-existing political ideologies. For example, right-wing populists (Schain, Zolberg and Hossay, 2002; Ignazi, 2003; Norris, 2004; Kriesi \& Pappas, 2015; Greven, 2016; Mudde 2016) or left populisms (Pappas, 2014; Mouffe, 2016), are the concrete situations in which the populist leader fills the programmatic vacuum nucleus around which the populist phenomenon develops with some (but never all) of the ideal and programmatic content typical of a preformed political ideology and therefore available for symbolic hybridization processes.

The second dimension along which Populism must be reconstructed and analyzed is its own peculiar discourse logic, a specific mode of constructing political discourse that can not, for example, be left out of a continent of manichean division of the political field. The people are therefore always evoked 'by contrast and opposition', it can not exist unless it is in the presence of its enemies' (Laclau, 2005). There is no people, within the symbolic populist universe, if not in opposition to something or someone. It can only be summoned 'by contrast and difference'.The construction of political discourse by the populists is therefore of a "schmittian" nature, that is, it conceives and proposes a dichotomic friend / enemy politics within which the space for equally legitimate living of the positions and interests and for their partial and temporary composition tends to be depopulated if not quite obliterated. It is probably not a case that the most important political manifesto produced by the ideologist of the Italian populist movement Cinque Stelle, Gianroberto Casaleggio, is titled "We are in War" (Casaleggio and Grillo, 2011) to reiterate if it is needed that the universe symbolic reference is that of 
radical and extreme conflict, of the 'deadly' fight against enemies. Although the consequences of this discourse logic are often overwhelming or declining in ways that seem to be compatible with democratic politics, it is better to say it clearly and once in the past: populist speech, understood in the simplicity of its ideal-type form, it is not a democratic discourse as it denies the root elements of pluralism. In particular, ideologically populist subjects tend to deny the legitimacy of political competitors, disregarding the representative capacity of the people and relegating them to the role of enemies and traitors of the people.

In the last dimension, this popular democracy doctrine that we call populism is in connection with a specific and sufficiently widespread 'forma mentis' expressing the specific figure of the psychological relationships between leaders and followers, but also among the followers themselves itself an important element that distinguishes it from other organizational phenomena that concern democratic pluralism. Populism is linked with historical moments that see the rapid development of profound economic and social transformations and is "characteristic of periods of de-alignment that involve the radical rewriting of the social boundaries along which the society was previously structured "(Polany, 1974, Panizza et al., 2005: 14) It is therefore a phenomenon that develops in close correlation with the crisis of pre-existing identities and is, from a psychological and social point of view, a process of de-identification from previous identities and re-identification with the new populist identity (Ivi: 10). Thus, "a populist identity emerges from the displacement of specific identities of bearers of particular questions (confinants, workers, peasants, unemployed, women, ethnic groups, etc.) and their reintegration into the imaginary unity of the people" (Ivi: 14) . In this, populism "is usually a reaction to the feeling that the foundations of the community to which it refers are disintegrating" (Tarchi, 2016: 6). The populist leader feeds the anguish resulting from the (partial) loss of the identity created by the economic-technological-social upheavals by focusing on some key objects that seem clearly identifiable and necessarily involve the existence of one or more enemies. He daily remembers, with great emphasis, the existence of these dangers and their enemies to fight (potential terrorist immigrants who steal jobs and homes to those legitimately entitled, corrupt politicians, bureaucrats ineffective and arrogant, parasitic intellectuals, serving and lying journalists, unscrupulous economic lobbies, oppressive international institutions, foreign powers shading in the shadows, etc.) thus fueling the state of collective anguish, giving it an intelligible form and providing pseudo-explanations that reflect the opposing dichotomous dynamics that have been repeatedly mentioned in order to allow the identification of scapegoats to which the evoked anguish catalyses. The solutions proposed are simple, radical and it is not uncommon to use symbolic 
and verbal violence. They are, in most cases, demagogic solutions as no realistic means, procedures and direct and indirect costs, which would arise from their adoption, are never explicitly disclosed. What matters is not the realization of the same, but the suggestion that they are capable of generating towards their followers and the degree of attention they can bring to an everfragmented and unbiased public identity. Populist politics is, from a psychological point of view, a policy that is based on the radicalization of the dichotomy of mistrust / confidence. Just as the mistrust is high on professional politicians, the ability to represent the true interests of the people, the institutions, and in all the subjects that can be considered as enemies, likewise trust is the ultimate in respect to the leader, outsiders not spotted by the original sin of politics acting as "living theory" (Tarchi, 2016: 6). And if the process of mass identification in one leader is 'the normal way of contemporary politics', populist identification has some specific characteristics. In particular, the leader presents itself as a 'political outsider' and 'one of the people', thus placing himself on a plan of perfect parity and consonance with his (potential) followers. Officially, he does not possess any special quality, which would bring him outside the people, except that he has seen in a clearer way the truth that is unfairly denied and hidden by other political actors. In this sense, populist leadership, if investigated through the concept of charisma, is an interesting oxymoron. The populist leader presents himself as 'one of the people' without any extraordinary quality, but at the same time the language that he speaks is the revelation of the truth concealed by power, and the way he points to is that of moral regeneration of politics by neutralizing enemies of the people with forms ranging from simply defeating electoral to incarceration or physical elimination by passing through 'scraping'. The overall approach to speech is therefore of a highly charismatic type, and it is not by chance the only true communicative code that it uses is that given by true / false dichotomy. What the populist leader says is always and evidently true 'by definition' and disinterested, while what the enemies say is always and in any case false, dictated by the interest of part or the result of pure wickedness. Since populism is a 'moral policy' that wants to do 'moral politics', it can only use the commodity code just mentioned. And while it is true that this code is normally used within political competition, it is worth noting that the radical separation between true and false implemented by genuinely populist leaders is very often carried out within a broader discursive context that is absolutely peculiar: the conspiracy. The plot is the deus-ex-machina of populism; a pseudo-explanation that is sometimes generic and sometimes overly detailed but always based on invented or manipulated information that can nourish and nourish populist paranoia given that "the current populist heart supports democracy but does not want to be cheated by political machinations "(Mudde, 2004). It is no coincidence that conspiracy theories and populisms 
are intriguing often and willingly. On the other hand, the psychological root of populism and conspiracy is the same; both phenomena aim to "regain control and predictability" (Whitson \& Galinsky, 2008; Sullivan, Landau \& Rothschild, 2012), through the psychologically compensatory action given by the identification of enemies to be fought in a world shaken by profound transformations that questioned identities acquired from a deep and generalized mistrust in others. Both phenomena provide pseudo-explanations of phenomena that are not easily understood due to their wide scope, psychological weight, and the amount of consequences difficult to calculate. The key point is that these tautological pseudo-explanations work if the source that proposes and supports it is believed to be absolutely credible. It is the bond of trust that is established both horizontally and vertically within the 'reactive mobilization communities', such as the populist or conspiratorial ones that hold it together, and this bond depends very strongly on sharing strong feelings of distrust towards the world external and have identified the same enemies as a source of their own dissatisfaction situation. In the case of the mentality characteristic of the populist style, this psychological propensity deriving from a latent and confused state of dissatisfaction is directed by the leader towards specific targets and used as a lever for political mobilization. This task becomes simpler when developing rapid and important technological changes that invest in the field of mass political communication. These changes, in fact, push for disintermediation between leaders and voters, and at the same time question the authority of the sources of information that until then dominated the communicative space (Diamonds, 2014). As the advent of the radio became inextricably linked to the affirmation of the fascist, Nazi, and Communist populist movements, today the widespread internet diffusion allows two fundamental reasons for the emergence of populist actors: 1) a further disintermediation between leaders and citizens who assumes forms of interactivity that is only comparatively comparable but which, however, reduces the hierarchical differential between leaders and citizens over the oneway and top-down communication typical of television; 2) the creation of "alternative" low cost informational sources with broad dissemination potential to traditional ones through which to spread the 'truths' to illuminate the people and the 'censored news' that the corrupt system of traditional media does not carry because it is an integral part of the 'conspiracy against the people'.

\section{Conclusion}

To summarize, our definition of populism as a multidimensional phenomenon: 1) refuses to see existing definitions of populism as mutually exclusive; 2) distinguishes between regulatory dimension and empirical realization of the same as is the case for the concept of democracy; 3 ) identifies 
the normative dimension of the concept with a political doctrine expressing a peculiar vision of democracy; 4) notes that this doctrine produces a radical policy based on the creation of non-negotiable collective identities, but does not have a peculiar design nucleus, a situation that allows any hybridization with the existing political ideologies; 5) conceives this doctrine as a real political phenomenon only in connection with a 'characteristic mentality', that is, with a more or less diffused cultural and psychological substrate that represents its consensual humus and which determines specific and peculiar relationships between leaders and followers (hence the question of the charismatic nature of populist leadership); 6) agrees with the literature that identifies a specific populist mode of constructing political discourse, but does not reduce the whole populist phenomenon to this discursive logic or to a peculiar political style, but see in it one of the key elements to be analyzed. Finally it should be said is not necessary that the two constituent dimensions of the identified populism (normative and empirical) must coexist. If the assumption of the doctrinal-normative dimension by a political leader is normally a corollary of a development of political practice that reflects all or many of the tools and techniques of popular consensus seeking populism, it is possible that certain elements of the practical populist politics (ex. psychological dimension and technique of building political discourse) can be used in different degrees by political actors who do not take the populist doctrine as a normative reference. In the first case, that is, in the situation in which both dimensions of populism are present and developed explicitly, one can speak for example of 'integral populism', or 'full developed populism' that is, of a closed symbolic universe within which political practice, collective identity and normative dimension show a high degree of internal coherence and tend to strengthen and bind each other. We swear then in the presence of a populism that is very close to its idealtipic shape. In the second case, that is, when only the empirical-practical dimension will be taken from the political leader of the turn, we will find ourselves in a plurality of political proposals which, with varying degrees and accents, will use a logic of speech or some style rhetoric typical of populism in strictly utilitarian and economic context. In such cases, it would be more appropriate to ask how different actors appear to be populists and, secondly, how and why they have borrowed some practical tools of populism without sharing the fundamental doctrinal axioms.

\section{References:}

1. Abts, K., Rummens, S. (2007). Populism versus Democracy. Political Studies, Vol.55, pp. 405-424

2. Arditi B. (2003). Populism, or Politics at the Edges of Democracy. Contemporary Politics, Vol. 9 (1), pp. 17-31 
3. Arditi, B. (2004). Populism as a Spectre of Democracy: A Response to Canovan. Political Studies, Vol.52, pp. 135-143

4. Bobbio, N. (1984). Il futuro della democrazia. Torino, Einaudi

5. Canovan, M. (1981). Populism. New York and London, Hartcourt Brace Janovich

6. Canovan, M. (1999). Trust the People! Populism and the Two Faces of Democracy. Political Studies, 47 (1), 2-16

7. Cartocci, R. (1996). L'Italia unita del populismo. Rassegna Italiana di Sociologia, XXXVII, 2, aprile-giugno

8. Casaleggio, G. \& Grillo, B. (2011), Siamo in guerra. Per una nuova politica, Milano, Chiarelettere

9. Chiapponi, F. (2009), Populismo, leadership e carisma, paper presented at the annual meeting of the Società Italiana di Scienza Politica

10. Freeden, M. (1998). Is Nationalism a Distinct Ideology? Political Studies, XLVI, 4, 1998, p. 750

11. Greven, T. (2016). The Rise of Right-wing Populism in Europe and the United States, A Comparative Perspective. Freidrich Ebert Stiftung papers

12. Hawkins, K., Riding S., Mudde, C. (2012). Measuring Populist Attitudes. C\&M Working Paper (\#55)

13. Ignazi, P. (2003). Extreme Right Parties in Western Europe. Oxford, Oxford University Press

14. Ionescu, G., Gellner, E. (1969). Populism, Its Meanings and National Characteristics. 1st Ed., London, Weidenfeld and Nicoloson, 1st American Ed., New York, Macmillan

15. Jagers, J., Walgrave, S. (2007). Populism as political communication style: An empirical study of political parties' discourse in Belgium. European Journal of Political Research, Vol.46, Issue 3, pp. 319- 345

16. Kazin, M. (1995). The Populist Persuasion: An American History. New York, Basic Books

17. Kriesi, H., Pappas, T. (2015), (eds). European Populism in the Shadow of the Great Recession. Colchester, ECPR Press

18. Laclau, E. (2005). Populism: What's in a Name?. in Panizza, F., et al. (2005). Populism and the Mirror of Democracy. London - New York, Verso

19. Linz, J.J. (1975). Totalitarian and Authoritarian Regimes. in Polsby, N., Greenstein F. (eds.). Handbook of Political Science. Vol. 3: Macropolitical Theory, Reading, Mass., Addison-Wesley, pp. 175411 
20. Meny Y., Surel, Y. (2002), (eds). Democracy and the Populist Challenge. New York, Palgrave.

21. Mudde, C. (2004). The Populist Zeitgeist. Government and Opposition, XXXIX, 4, pp.541-563

22. Mouffe, C., Errejon, I. (2016). Podemos: in the Name of the People. London, Lawrence \& Wishart

23. Norris, P. (2004). Radical Right. Voters and Parties in the Electoral Market. Cambridge, Cambridge University Press

24. Panizza, F. et. al. (2005). Populism and the Mirror of Democracy. London-New York, Verso.

25. Pappas, T. (2014). Populism and Crisis Politics in Greece. New York, Palgrave Macmillan

26. Polany, K., (1974), The Great Transformation, Torino, Einaudi

27. Sartori, G. (1993). Democrazia. Cosa è. Milano, Rizzoli

28. Sartori, G. (2011). Logica, metodo e linguaggio nelle scienze sociali. Bologna, Il Mulino

29. Schain, M., Zolberg, A., Hossay, P. (eds.), (2002). Shadows of Europe: The Development and Impact of Extreme Right in Western Europe. New York, Palgrave Macmillan

30. Sullivan, D., Landau, J.M., \& Rothschild, Z. (2012), An existential function of enemyship: Evidence that people attribute influence to personal and political enemies to compensate for threats to control. Journal of Personality and Social Psychology, 98, pp. 434-494

31. Taguieff, P. (1995). Political science in the face of populism: from a conceptual mirage to a real problem. Telos, Vol.103, pp. 9-43

32. Taggart, P. (2004). Populism and Representative Politics in Contemporary Europe. Journal of Political Ideologies, Vol.9, Issue 3, pp. 269- 288

33. Tännsjö, T. (1992). Populist Democracy: a Defense. London, Routledge.

34. Tarchi, M. (2015). Italia populista. Dal qualunquismo a Beppe Grillo. Bologna, Il Mulino

35. Urbinati, N. (1998). Democracy and Populism. Constellations, Vol.5 (1), pp. 110-124

36. Urbinati, N. (2014). Democracy Disfigured. Opinion, Truth and the People. Cambridge, Harvard University Press

37. Whitson, J. A., \& Galinsky, A.D. (2008). Lacking control increases illusory pattern perception. Science, 322, pp. 115-117

38. Zanatta, L. (2002). Il populismo. Sul nucleo forte di un'ideologia debole. POLIS, $n .2$ / 2002, pp. 263-292 